\title{
Co-secretion of calcitonin gene-related peptide, gastrin- releasing peptide and ACTH by a carcinoid tumour metastasizing to the cerebellum
}

\author{
M.A. Ghatei, M.R. Stratton', J.M. Allen, G.F. Joplin, J.M. Polak ${ }^{2}$ and S.R. Bloom \\ Departments of Medicine, ${ }^{1}$ Histopathology and ${ }^{2}$ Histochemistry, Hammersmith Hospital, Royal Postgraduate \\ Medical School, London W12 0HS, UK.
}

\begin{abstract}
Summary: A carcinoid tumour presenting as Cushing's syndrome is reported. Although no tumour mass could be initially identified the patient returned with first a liver and subsequently a cerebellar mass both of which were resected. Only at post-mortem was the lung primary discovered. ACTH, gastrinreleasing peptide (GRP) and calcitonin gene-related peptide were elevated in plasma before resection of the hepatic tumour. These peptides were demonstrated in both the hepatic and cerebellar tumours by immunocytochemistry and radioimmunoassay. This case illustrates the occasional tendency of primary lung carcinoids to remain small and clinically undetectable while generating secondary tumours which are symptomatic. It is suggested that immunological demonstration of GRP may be diagnostically helpful in directing attention to the lung as a primary site in neuroendocrine tumours which present in this fashion.
\end{abstract}

\section{Introduction}

Gastrin-releasing peptide (GRP), a peptide of 27 amino acid residues, ${ }^{1}$ and its $C$-terminal decapeptide ${ }^{2,3}$ (neuromedin C), are now considered to be the mammalian forms of bombesin. ${ }^{4}$ Both amphibian bombesin and its mammalian counterparts have potent pharmacological effects in the gastrointestinal tract and the central nervous system. Infusion in man has shown that both bombesin and GRP release gastrointestinal and pancreatic hormones. ${ }^{5,6}$ Bombesin and GRP-like immunoreactivity have been reported in oat cell carcinoma of the bronchus ${ }^{7,8}$ where production of these peptides is frequently associated with calcitonin $^{9,10}$ and ACTH. ${ }^{11,12}$

Recently, a new peptide, 'calcitonin gene-related peptide' (CGRP), has been isolated. This 37 amino acid residue peptide is a product of mRNA formed by alternative tissue-specific RNA splicing after transcription of the calcitonin gene. ${ }^{13}$ Human CGRP has been isolated from medullary carcinoma of the thyroid ${ }^{14}$ and from a cell line derived from small cell carcinoma of the bronchus, ${ }^{15}$ but its secretion from other neuroendocrine tumours has not previously been reported.

We report here a patient who presented with ectopic

Correspondence: Professor S.R. Bloom D.Sc., F.R.C.P. Accepted: 27 August 1986
ACTH secretion syndrome resulting from a metastatic carcinoid tumour of pulmonary origin, which was found in addition to contain and secrete three forms of gastrin-releasing peptide (bombesin) and CGRP.

\section{Case report}

A 49 year old Caucasian male presented in September 1980 with clinical and biochemical features of ectopic ACTH secretion syndrome. Despite extensive radiological investigation including ultrasonography, computerized tomographic (CT) scanning and selective venous sampling, the source of ACTH secretion was not identified. He was treated with potassium supplements and metyrapone, but his symptoms became increasingly difficult to control and he therefore underwent bilateral adrenalectomy by the posterior route. The adrenals were hyperplastic (left adrenal $15 \mathrm{~g}$; right adrenal $16 \mathrm{~g}$ ). Post-operative steroid replacement therapy was started, but over the next two years the patient became hyperpigmented. Further investigations were negative until, in May 1982, a technetium- $99 \mathrm{~m}$ liver scan revealed a large filling defect in the right lobe of the liver. Angiography and CT scan confirmed the presence of a mass, and in June 1982, a malignant hepatic tumour $9 \mathrm{~cm}$ in

(C) The Fellowship of Postgraduate Medicine, 1987 
diameter was removed by right lobectomy. No other tumour was found at laparotomy. Postoperatively, the pigmentation faded. The patient remained well until October 1983 when he presented with ataxia and dysarthria. CT scan showed a cystic right cerebellar tumour, and vertebral angiography demonstrated an intrinsic avascular mass in the right cerebellar hemisphere which was subsequently resected. Postoperatively his ataxia and dysarthria improved considerably.

Eighteen months later he again deteriorated with reemergence of neurological symptoms and the onset of obstructive jaundice leading to his death in April 1985.

At post-mortem there was a tumour in the porta hepatis invading the portal vein and occluding the common bile duct. A single nodule was present in the liver and dissection of the brain revealed deposits in the left parietal area and pineal gland. An ill defined $1 \mathrm{~cm}$ diameter firm area was noted in the upper lobe of the right lung. Histological examination confirmed this to be a tumour similar in appearance to that resected previously from liver and brain.

\section{Materials and methods}

\section{Radioimmunoassay}

During the course of his illness, fasting blood samples $(10 \mathrm{ml})$ were obtained from the patient, and placed in chilled heparinized tubes containing $200 \mu$ l aprotinin (Trasylol - Bayer). Plasma was separated within 20 minutes and stored frozen for measurement of concentration of ACTH, GRP and CGRP.

Peptides were extracted from tumour tissue by boiling in $0.5 \mathrm{M}$ acetic acid (10\% weight/volume) for 10 minutes. The concentration of GRP was determined by radioimmunoassay as described previously. ${ }^{16}$ CGRP concentration were measured using a rabbit antiserum (MJ-2) raised against synthetic human CGRP (Bachem Laboratories) conjugated to bovine serum albumin (BSA) with carbodiimide and used at the final dilution of $1: 320,000$. This antiserum does not cross react with calcitonin or other known regulatory peptides. Radiolabelled CGRP was prepared by a chloramine-T iodination of the histidine residue in synthetic human CGRP and purified by reverse-phase high pressure liquid chromatography (HPLC) on a $\mu$ Bondapak C-18 column. The assay was performed in a total volume of $0.8 \mathrm{ml}$ of phosphate buffer $(0.06 \mathrm{M}, \mathrm{pH} 7.4)$ containing $0.01 \mathrm{M}$ EDTA and $3 \%$ BSA. For assays of plasma GRP and CGRP, $100 \mu \mathrm{l}$ samples were used and all standard and assay control tubes contained $100 \mu \mathrm{l}$ pooled human time expired plasma from which peptide immunoreactivities had been removed by charcoal absorption. Chromatography of these plasma samples on Sephadex G-50 column revealed no peaks of GRP or CGRP-like immunoreactivity. After 5 days' incubation at $4^{\circ} \mathrm{C}$, free label was separated from antibodybound label by adding $8 \mathrm{mg}$ dextran-coated charcoal per tube. The sensitivity of the assay was $1.5 \mathrm{fmol} /$ tube (95\% confidence limit). Plasma ACTH-immunoreactivity was kindly measured by Professor L.H. Rees (Department of Chemical Endocrinology, St Bartholomews Hospital, London). ${ }^{17}$

\section{Chromatography}

Tissue extracts and plasma were loaded onto a Pharmacia column $(1.5 \times 100 \mathrm{~cm})$ containing Sephadex $\mathrm{Gg}$ 50 Superfine, which was eluted at $4^{\circ} \mathrm{C}$ with 0.06 phosphate buffer, $\mathrm{pH} 7.4$, containing $0.01 \mathrm{~mol} / \mathrm{s}$ EDTA, $0.3 \% \mathrm{BSA}$, and $0.2 \mathrm{~mol} / \mathrm{l}$ sodium chloride at flow rate of $3 \mathrm{ml} / \mathrm{h}$. The column was recalibrated between each series of runs with dextran blue (molecular weight $2 \times 10^{6}$, elution coefficient, $\mathrm{Kav} 0$ ), horse heart cytochrome C (molecular weight 12,384, $\mathrm{Kav} 0.23)$ and $\mathrm{Na}^{125} \mathrm{I}(\mathrm{Kav} 1)$ as molecular size markers. Kav was calculated according to Laurent \& Killander. ${ }^{18}$ GRP and CGRP immunoreactivities detected in the tumour extracts were further analysed by HPLC on a Techsil C-18 (Water Associates Inc.) reverse phase column $(3.9 \times 300 \mathrm{~mm})$. A linear gradient elution system was used from 15 to $40 \%$ acetonitrile in water containing $0.05 \%$ trifluoroacetic acid over 75 minutes. The flow rate was $1 \mathrm{ml} / \mathrm{min}$ and fractions of $1 \mathrm{ml}$ were collected. Fractions from the gel

Table I Characterization of antibodies for immunocytochemistry

\begin{tabular}{lcccr}
\hline Antiserum & \multicolumn{1}{c}{ Method of conjugation } & Titre & Antigen concentration* \\
\hline NSE (human) & - & - & $1 / 4000$ & 1.0 \\
ACTH & CDI & BSA & $1 / 2000$ & 10.0 \\
Bombesin & BDB & BSA & $1 / 4000$ & 10.0 \\
CGRP & CDI & BSA & $1 / 2000$ & 10.0 \\
\hline
\end{tabular}

* nmol of antigen required per $\mathrm{ml}$ of diluted antiserum to prevent immunostaining.

CDI, carbodiimide; BDB, bid-diazotized benzidine; BSA, bovine serum albumin. 
columns and HPLC were assayed at different dilutions for both GRP and CGRP-like immunoreactivities.

\section{Immunocytochemistry}

Surgically resected hepatic and cerebellar tumour tissue were separately fixed in $10 \%$ buffered formalin and in Bouin's solution. Other fragments were immediately frozen and subsequently freeze-dried and vapour-fixed in benzoquinone. ${ }^{19}$ Tissue obtained at post-mortem was fixed in $10 \%$ formaldehyde solution. All tissues, whether fixed in solution or vapour-fixed, were embedded in paraffin wax. Sections were stained with haematoxylin and eosin, Grimelius silver impreg- nation technique ${ }^{20}$ and by immunocytochemistry, ${ }^{21}$ using antibodies to neurone-specific enolase, ${ }^{22}$ a marker for neuroendocrine differentiation, and peptide hormones including ACTH, GRP/bombesin and CGRP (see Table I for antibody characterization). In order to demonstrate the presence of more than one peptide within a single cell, pairs of $3 \mu \mathrm{m}$ serial sections were cut. The first section of each pair was inverted before being picked up on a glass slide. Pairs of sections were stained for ACTH and CGRP, CGRP and GRP and GRP and ACTH. For electron microscopy, small fragments of tumour were fixed in $2.5 \%$ glutaraldehyde and subsequently post-fixed in osmium tetroxide.
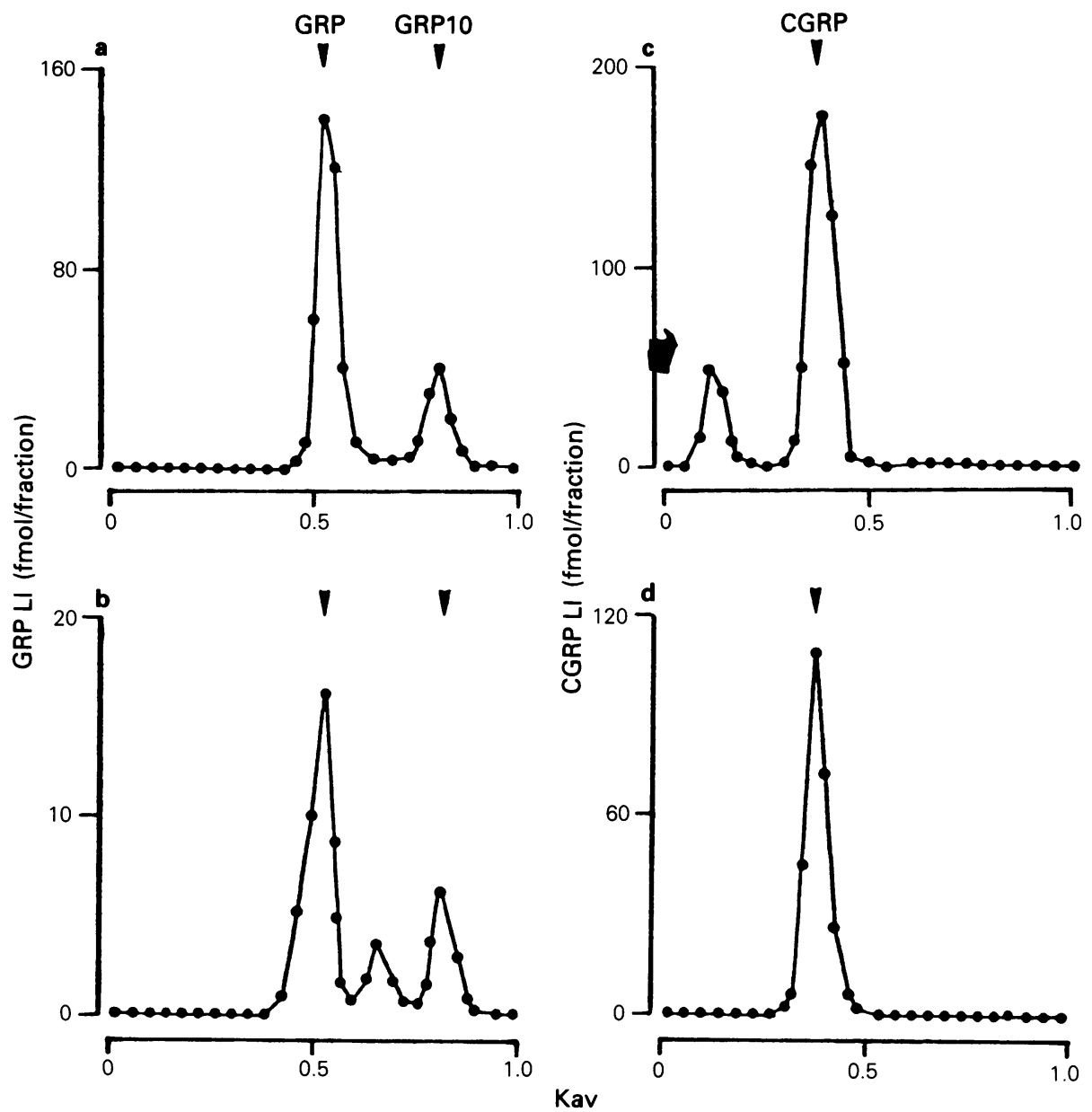

Figure 1 Gel permeation chromatographic profiles of GRP (GRPLI) and CGRP-like (CGRPLI) immunoreactivities of tumour extract $(a, c)$, and pre-operative plasma $(b, d)$ on a Sephadex G-50 superfine column $(1.5 \times 100 \mathrm{~cm})$. GRP, synthetic porcine gastrin-releasing peptide; GRP10, synthetic porcine C-terminal decapeptide of gastrin-releasing peptide (neuromedin C); CGRP, synthetic human calcitonin gene-related peptide. 


\section{Results}

\section{Radioimmunoassay of plasma}

Analysis of plasma samples taken prior to partial hepatectomy showed a raised level of ACTH at $539 \mathrm{ng} / 1$, GRP $180 \mathrm{pmol} / 1$ (normally undetectable, i.e. $<10 \mathrm{pmol} / \mathrm{l}$ ) and CGRP $420 \mathrm{pmol} / 1$ (normally undetectable, i.e. $<20 \mathrm{pmol} / \mathrm{l})$. After right hepatectomy plasma levels of ACTH fell to $63 \mathrm{ng} / \mathrm{l}$ while CGRP and GRP became undetectable.

\section{Radioimmunoassay of tumour}

Extracts from the tumour resected from the right hepatic lobe contained $2.4 \mathrm{nmol} / \mathrm{g}$ of GRP and $130 \mathrm{pmol} / \mathrm{g}$ of CGRP-like immunoreactivity. The cerebellar tumour contained $1.2 \mathrm{nmol} / \mathrm{g}$ GRP and $96 \mathrm{pmol} / \mathrm{g}$ CGRP.

\section{Chromatographic analysis}

Gel permeation chromatography of the preoperative plasma and the tumour extracts demonstrated two major GRP-like immunoreactive peaks (Figure 1a,b). The earlier peak (Kav 0.54) emerged in the position of synthetic porcine gastrin-releasing peptide
(GRP), while the second minor peak was co-eluteç with C-terminal decapeptide of GRP (Kav 0.81) jus? after amphibian bombesin (Kav 0.78). Analysis of the tumour extracts on reverse phase HPLC revealed threes major peaks of GRP-like immunoreactivity (Figure 2 ), in which only a proportion of the immunoreactivityo had an identical retention time to that of C-termina decapeptide of GRP (Figure 2). Neither of the othe two immunoreactive peaks corresponded to either pure synthetic porcine GRP or synthetic amphibian? bombesin.

Analysis of the tumour extracts on the gel column revealed two major CGRP immunoreactive peak少 (Figure 1c). The earlier peak of Kav 0.17 was elute产 between the dextran blue and cytochrome $\mathrm{C}$, indicat 3 ing a larger molecular form, whereas the second peaks was co-eluted with synthetic human CGRF (Kav 0.37). In contrast, however, the pre-operatives plasma contained only one major molecular form of CGRP-like immunoreactivity which emerged in the position of synthetic human CGRP (Figure 1d).

\section{Histology of tumour tissue}

The hepatic, cerebellar and pulmonary masses showect similar histological features. They were composed of ribbons, trabeculae, acini and irregular masses ofot

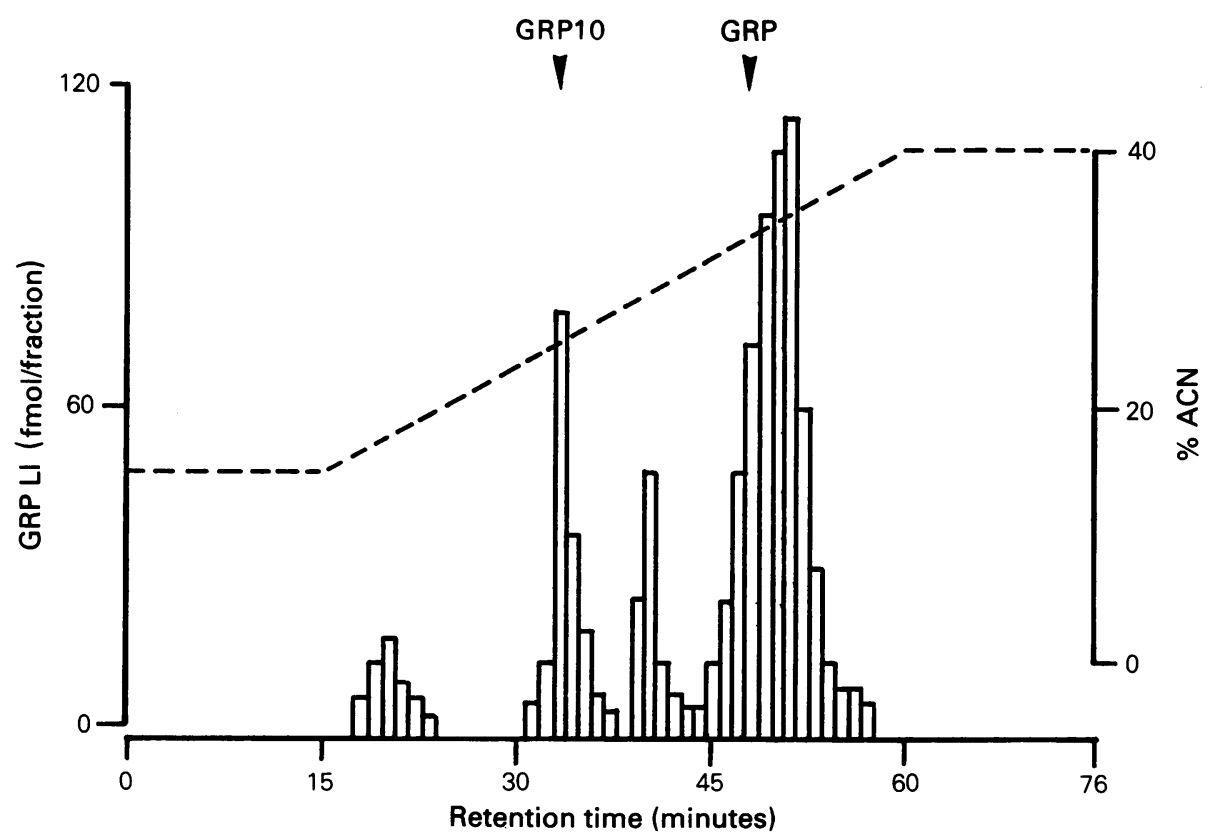

Figure 2 Reverse phase high pressure liquid chromatography analysis of GRP-like (GRPLI) immunoreactivity of the tumour tissue extract. The column was eluted with a gradient (dotted line) between two acetonitrile (ACN) $0.05 \%$ aqueous TFA solvent system. From $15 \%$ to $40 \%$ by volume acetonitrile. 


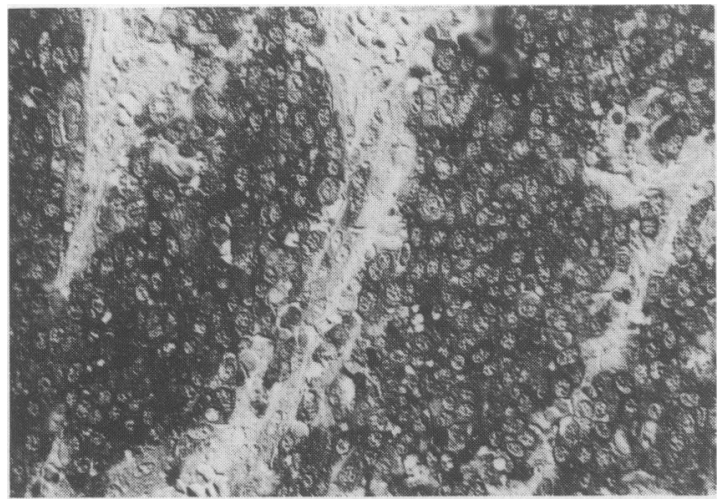

Figure 3 NSE immunoreactivity in the cells of the liver tumour. Freeze-dried, benzoquinone vapour-fixed tissue; $5 \mu \mathrm{m}$ wax-section. Photographed using Normarski interference contrast; $\times 700$.

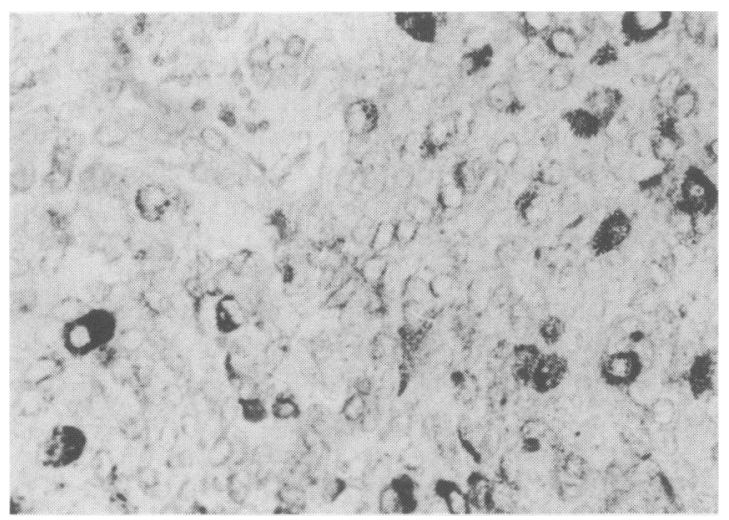

Figure 4 GRP-immunoreactivity in the cells of liver tumour. Freeze-dried, benezoquinone vapour-fixed tissue; $5 \mu \mathrm{m}$ wax-section; $\times 900$.

monomorphic polygonal cells with high nuclear: cytoplasmic ratio, eosinophilic granular cytoplasm and slightly irregular hyperchromatic nuclei showing normal and abnormal mitoses. The lung tumour occupied the lumen of a bronchus and had infiltrated through its wall to invade adjacent lung parenchyma.

Immunocytochemistry with antiserum to neuronespecific enolase, showed reactivity in all tumour cells, albeit of variable intensity (Figure 3 ). Numerous diffusely spread tumour cells throughout the tumours reacted also to antibodies to ACTH, GRP/bombesin (Figure 4) and CGRP.

Co-localization studies using serial, mirror image sections demonstrated the co-existence of ACTH and CGRP, CGRP and GRP and ACTH and GRP within

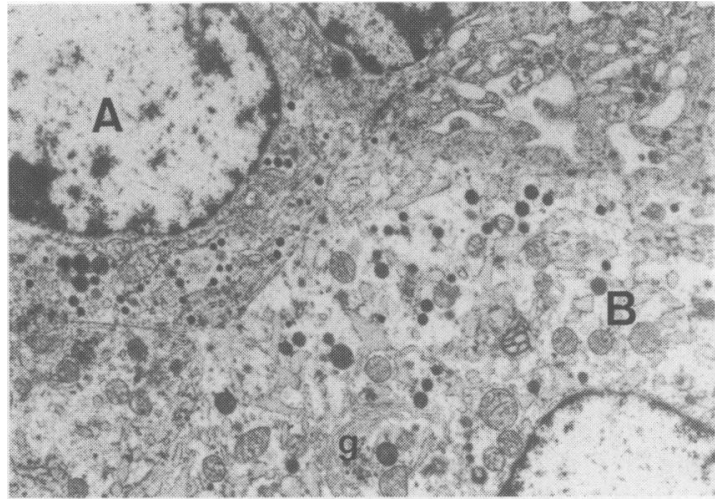

Figure 5 Electron micrograph of two distinct endocrine cell types from ACTH-producing tumour-cell type A exhibits the conventional ultrastructural appearance of ACTH-containing secretory granules $\left(D_{\max }=160 \mathrm{~nm}\right)$ whereas cell $B$ contains much larger $\left(D_{\max }=220 \mathrm{~nm}\right)$ electron-dense secretory granules. Both cell types were immunoreactive against ACTH antisera. A prominent Golgi apparatus (g) is present in cell B. Gluteraldehyde fixation/osmium tetroxide/araldite/uranyl acetate and lead citrate counterstain, $\times 13,200$.

single cells. Electron microscopy revealed the presence of two endocrine cells types containing dense core secretory granules measuring approximately $230 \mathrm{~nm}$ and $160 \mathrm{~nm}$ in diameter (Figure 5).

\section{Discussion}

Cushing's syndrome due to ectopic production of $\mathrm{ACTH}$ is a well recognized complication of neuroendocrine tumours, in particular small cell carcinoma of the bronchus. When tumor mass is small it may be the only manifestation and thus the presenting feature. Indeed the source of ACTH in this case eluded imaging techniques until 2 years after presentation when a hepatic mass and subsequently a posterior fossa deposit were detected. Nevertheless during life the tumour primary site remained unclear. Although primary neuroendocrine tumours of the liver have been reported, ${ }^{23}$ these are uncommon and at the present limit of resolution of imaging techniques the diagnosis may only be confidently made at postmortem when alternative more likely sites can be excluded.

When this patient came to autopsy a small pulmonary nodule was discovered. We consider this to be the primary for several reasons. These include the relative frequency of bronchial carcinoids, the presence of cranial metastases (common in pulmonary tumours) and the histological demonstration that the tumour 
was present within a bronchus. Although a satisfactory retrospective diagnosis was possible, were there any other clues to the origin of the primary available during life?

Analysis of plasma and tumour extracts together with immunohistochemical examination of tissue sections suggested that three peptides were being synthesized and secreted by the carcinoid; ACTH, responsible for the Cushing's syndrome, gastrin-releasing peptide (GRP, bombesin) and calcitonin gene-related peptide (CGRP). In normal human tissues GRP-like immunoreactivity has been demonstrated predominantly in endocrine cells of the fetal and neonatal lung. ${ }^{24,25,26} \mathrm{~A}$ number of common neoplasms also synthesize GRP, which occurs in two major molecular forms distinguishable by gel chromatography, small cell carcinoma of the bronchus, ${ }^{7,8,9,27,28}$ bronchial carcinoids $^{29,30,31,32}$ and medullary carcinoma of the thyroid. ${ }^{32-36} \mathrm{~A}$ thyroid neoplasm is usually easily excluded clinically and therefore we suggest that GRP synthesis is a strong indicator of pulmonary origin and should direct attention to the lung in cases such as this in which the primary site is obscure.

GRP is thought to have a number of biological effects including release of many gastrointestinal hormones. This may be demonstrated by infusion of GRP into healthy volunteers at lower levels than were present in this patient. ${ }^{5,6,37}$ Nevertheless no other gastrointestinal hormone was elevated in this case, a finding which is generally consistent with reports of patients with elevated plasma GRP immunoreactivities. The lack of stimulatory effect is unlikely to be due to the production of biologically inactive forms of the molecule as the antiserum used for radioimmunoassay reacts with the active site of GRP. It is conceivable, however, that chronic GRP secretion from a slowly developing tumour may be associated with down regulation of GRP receptors and consequent lack of effect. This is similar to the lack of effect of elevated plasma somatostatin concentrations in patients with somatostatinomas. ${ }^{38,49}$

Carcinoid tumours of the bronchus are in general

\section{References}

1. McDonald, T.J., Jornvall, H., Nilsson, G. et al. Characterization of gastrin-releasing peptide from porcine nonantral tissue. Biochem Biophys Res Commun 1979, 90: 227-233.

2. Reeve, J.R., Walsh, J.H., Chew, P., Clark, B., Hawke, D. $\&$ Shively, J.E. Amino acid sequences of three bombesinlike peptides from canine intestine extracts. $J$ Biol Chem 1983, 258: 5582-5588.

3. Minamino, N., Kangawa, K. \& Matsuo, H. Neuromedin $\mathrm{C}:$ a bombesin-like peptide identified in porcine spinal cord. Biochem Biophys Res Commun 1984, 119: 14-20.

4. Anastasi, A., Erspamer, V. \& Bucci, M. Isolation and slow growing neoplasms with high 5 year survival rates. This patient's neoplasm is therefore one of the minority which behave aggressively and metastasize. This unusual behaviour may be associated with the autocrine growth regulatory activity or trophic effect ascribed to GRP. ${ }^{40,41}$ This has been demonstrated particularly convincingly on small cell carcinoma lines which synthesize GRP ${ }^{42}$ and confirmed by showing that antibodies which inhibit the binding of GRP receptors inhibit growth in vitro and tumour xenografts in vivo. ${ }^{42}$ It is conceivable that some bronchial carcinoids are under GRP autocrine control and that occasional aggressive tumours such as the one reported here synthesize and secrete particularly large amounts, accounting for their behaviour. Manipula- 8 tion of GRP autocrine control by use of antagonists or antibodies may provide future approaches to therapy of such tumours. ${ }^{42,43}$

The final unusual feature of this case is the synthesis and secretion of CGRP. Initially characterized by $\vec{N}$ isolation of its mRNA from cells of medullary carcin- $\omega$ oma of the rat thyroid ${ }^{13,44}$ and it has been demonstrated immunohistochemically in neurones of the central and peripheral nervous system and in thyroid C cells. ${ }^{13,45,46}$ T Among neoplasms it has been restricted to medullary carcinoma of the thyroid ${ }^{14}$ and a cell line derived from small carcinoma of the bronchus ${ }^{15}$ until demonstration in this case. The biological effects of CGRP are st being characterized although potent effects on the cardiovascular system ${ }^{47,48}$ have been described. Of the clinical features present in this case none could be ascribed to raised plasma CGRP levels.

\section{Acknowledgements}

We are grateful to Dr I.M. Varndell for electron microscopy, Dr J.H. Angel for referring the patient to us, Professor L.H. Rees for plasma ACTH measurement and to Professors R.B. Welbourn, L.H. Blumgart and L. Symon who all participated in his surgical case. We would like to thank the Medical Research Council for their financial support and Ms J. Chatterton for typing the manuscript. structure of bombesin and alytesin, two analogous active peptides from the skin of European amphibians Bombina and Alytes. Experientia 1971, 27: 166-167.

5. Ghatei, M.A., Jung, R.T., Stevenson, J.C.et al. Bombesin: action on gut hormones and calcium in man. J Clin Endocrinol Metab 1982, 54: 980-985.

6. Wood, S.M., Jung, R.T., Webster, J.D. et al. The effect of the mammalian neuropeptide, gastrin-releasing peptide (GRP), on gastrointestinal and pancreatic hormone secretion in man. Clin Sci 1983, 65: 365-371.

7. Moody, T.W., Pert, C.B., Gazdar, A.F., Carney, D.N. \& Minna, J.D. High levels of intracellular bombesin 
characterize human small cell lung carcinoma. Science 1981, 214: 1246-1248.

8. Wood, S.M., Wood, J.R., Ghatei, M.A., Lee, Y.C., O'Shaughnessey, D.J. \& Bloom, S.R. Bombesin, somatostatin and neurotensin-like immunoreactivity in bronchial carcinoma. J Clin Endocrinol Metab 1981; 53: 1310-1312.

9. Sorenson, G.D., Pettengill, O.S., Gate, C.C. et al. Bombesin and calcitonin secretion by pulmonary carcinoma is modulated by cholinergic receptors. Life Sci 1983, 33: 1939-1944.

10. Yamaguchi, K., Abe, K., Adachi, I. et al. Concomitant production of immunoreactive gastrin-releasing peptide and calcitonin in medullary carcinoma of the thyroid metabolism. Metabolism 1984, 33: 724-724.

11. Bayliss, S.B. \& Mendelsohn, G. Ectopic (inappropriate) hormone production by tumours: mechanisms involved and the biological and clinical implications. Endocrinol $\operatorname{Rev} 1980,1: 45-77$.

12. Gewirtz, G. \& Yalow, R. Ectopic ACTH production in carcinoma of the lung. J Clin Invest 1974, 53: 1022-1032.

13. Rosenfeld, M.G., Mermod, J.J., Amara, S.G. et al. Production of a novel neuropeptide encoded by the calcitonin gene via tissue-specific RNA processing. Nature 1983, 304: 129-135.

14. Morris, H.R., Panico, M., Etienne, T., Tippins, J., Girgis, S.I. \& MacIntyre, I. Isolation and characterization of human calcitonin gene-related peptide. Nature 1984, 308: 746-748.

15. Edbrooke, M.R., Parker, D., McVey, J.H. et al. Expression of the human calcitonin/CGRP gene in lung and thyroid carcinoma. EMBO J 1985, 4: 7.15-724.

16. Ghatei, M.A. Bombesin. In: Bloom S.R. and Long R.G. (eds) Radioimmunoassay of rat regulatory peptides. W.B. Saunders, London, 1982, pp 131.

17. Rees, L.H., Cook, D.M., Kendall, J.W. et al. A radioimmunoassay for rat plasma ACTH. Endocrinology 1971, 89, 254-261.

18. Laurent, T.C. \& Killander, J.A. Theory of gel-filtration and its experimental verification. J Chromatogr 1964, 14: 317-330.

19. Pearse, A.G.E. \& Polak, J.M. Bifunctional reagents as vapour- and liquid-phase fixatives for immunohistochemistry. Histochem J 1975, 7: 179-186.

20. Grimelius, L. \& Wilander, E. Silver impregnation and other non-immunocytochemical staining methods. In: Wright, N.A. and Azzopardi, J. (eds) Current Problems in Tumour Pathology, Vol. 1. Endocrine tumours. In: Polak, J.M. and Bloom, S.R. (eds). The pathobiology of regulatory peptide-producing tumours. Churchill Livingstone, Edinburgh, 1984.

21. Polak, J.M. \& Bloom, S.R. Immunocytochemistry of regulatory peptides. In: Polak, J.M. and Van Noorden, S. (eds) Immunocytochemistry Practical Applications in Pathology and Biology. John Wright and Sons, Bristol, London, Boston, 1983, p 184.

22. Tapia, F.J., Polak, J.M., Barbosa, A.J.A. et al. Neuronespecific enolase is produced by neuroendocrine tumours. Lancet 1981, i: 808-811.

23. Himsworth, R.L., Bloomfield, G.A., Coombes, R.C. et al. 'Big ACTH' and calcitonin in an ectopic hormone secreting tumour of the liver. Clin Endocrinol 1977, 7: 45-62.
24. Wharton, J., Polak, J.M., Bloom, S.R. et al. Bombesinlike immunoreactivity in the lung. Nature 1978, 273: 769-770.

25. Cutz, E., Chan, W. \& Track, N.S. Bombesin, calcitonin and leu-enkephalin immunoreactivity in endocrine cells of human lung. Experientia 1981, 37: 765-767.

26. Ghatei, M.A., Sheppard, M.N., Henzen-Hogman, S., Blank, M.A., Polak, J.M. \& Bloom, S.R. Bombesin and vasoactive intestinal polypeptide in the developing lung: marked changes in acute respiratory distress syndrome. $J$ Clin Endocrinol Metab 1983, 57: 1226-1232.

27. Erisman, M.D., Linnoila, R.L., Hernandez, O., DiAugustine, R.P. \& Lazarus, L.H. Human lung small cell carcinoma contains bombesin. Proc Natl Acad Sci USA, 1982, 79: 2379-2383.

28. Tsutsumi, Y., Osamura, Y., Watanabe, K. \& Yanaihara, N. Immunochemical studies on gastrin-releasing peptide and adrenocorticotropic hormone - containing cells in the human lung. Lab Invest 1984, 48: 623-632.

29. Roth, K.A., Evans, C.J., Weber, E., Barchas, J.D., Bostwick, D.G. \& Bensch, K.G. Gastrin-releasing peptiderelated peptides in a human malignant lung carcinoid tumour. Cancer Res 1983, 43: 5411-5415.

30. Tamai, S., Kameya, T., Yamaguchi, K. et al. Peripheral lung carcinoid tumour producing predominantly gastrin-releasing peptide (GRP); morphological and hormonal studies. Cancer 1983, 52: 273-281.

31. Yang, K., Ulich, T., Taylor, I., Cheng, L. \& Lewin, J. Pulmonary carcinoids, immunohistochemical demonstration of brain-gut peptides. Cancer 1983, 52: 819-823.

32. Price, J., Nieuwenhuijzen Kruseman, A.C., Doniach, I., Howlett, T.A., Besser, G.M. \& Rees, L.H. Bombesinlike peptides in human endocrine tumours. Quantitation, biochemical characterization and secretion. $J$ Clin Endocrinol Metab 1985, 60: 1097-1103.

33. Ghatei, M.A., Springall, D.R., Nicholl, C.G., Polak, J.M. \& Bloom, S.R. Gastrin releasing peptide likeimmunoreactivity in medullary thyroid carcinoma. Am J Clin Path 1985, 84: 581-586.

34. Howlett, T.A., Price, J., Hale, A.C. et al. Pituitary ACTH dependent Cushing's syndrome due to ectopic production of a bombesin-like peptide by a medullary carcinoma of the thyroid. Clin Endocrinol 1985, 22: 91101.

35. Kameya, T., Bessho, T., Tsumuraya, M. et al. Production of gastrin releasing peptide by medullary carcinoma of the thyroid. Virchows Arch A 1983, 401: 88-108.

36. Orloff, M.S., Reeves, J.R. Jr., Benawram, C.M., Shively, J.E. \& Walsh, J.H. Isolation and sequence analysis of human bombesin-like peptides. Peptides 1984, 5: 865-870.

37. Lezoche, E., Basso, N. \& Speranzo, V. Actions of bombesin in man. In: Bloom, S.R. and Polak, J.M. (eds) Gut Hormones. Churchill Livingstone, Edinburgh, 1981, p419.

38. Krejs, G.J., Orci, L., Conlon, J.M. et al. Somatostatinoma syndrome: Biochemical, morphologic and clinical features. N Engl J Med 1979, 301: 285-292.

39. Stacpoole, P.W., Kasselberg, A.G., Berelowitz, M. \& Chey, W.Y. Somatostatinoma syndrome: does a clinical entity exist? Acta Endocrinol 1983, 102: 80-87.

40. Kolata, G. Cell biology yields clues to lung cancer (research news). Science 1982, 218: 38-39. 
41. Willey, J.C., Lechner, J.F. \& Harris, C.C. Bombesin and C-terminal tetradecapeptide of gastrin-releasing peptide are growth factors for normal bronchial epithelial cells. Exp Cell Res 1984, 153: 245-248.

42. Cuttitta, F., Carney, D.N., Mulshine, J., Moody, T.W., Fedorko, J., Fiscler, A. \& Minna, J.D. Bombesin-like peptide can function as autocrine growth factor in human small-cell lung cancer. Nature 1985, 316: $823-826$.

43. Jensen, R.T., Jones, S.W., Folkers, K. \& Gardner, J.D. A synthetic peptide that is a bombesin receptor antagonist. Nature 1984, 309: 61-63.

44. Amara, S.J., Jonas, V., Rosenfeld, M.G., Ong, E.S. \& Evans, R.M. Alternative RNA processing in calcitonin gene expression generates mRNAs encoding different polypeptide products. Nature 1982, 298: $240-244$.

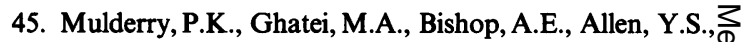
Polak, J.M. \& Bloom, S.R. Distribution and chromatographic characterisation of CGRP-like immunoreac-.. . tivity in the brain and gut of the rat. Regul Pept 1985, 12: 133-143.

46. Sabate, M.I., Stolarsky, L.S., Polak, J.M. et al. Regula-C tion of neuroendocrine gene expression by alternative RNA processing. Co-localization of calcitonin and cal- $-\bar{s}$ citonin-gene related peptide in thyroid C-cells. $J$ Biol Chem 1985, 260: 2589-2592.

47. Fisher, L.A., Kikkawa, D.O., Rivier, J.E. et al. Stimula-(ூ) tion of noradrenergic sympathetic outflow by calcitonin $\vec{\circ}$ gene-related peptide. Nature 1983, 305: 534-535.

48. Brain, S.D., Williams, T.J., Tippins, J.R., Morris, H.R. \& MacIntyre, I. Calcitonin gene-related peptide is a potent vasodilator. Nature 1985, 313: 54-56. 